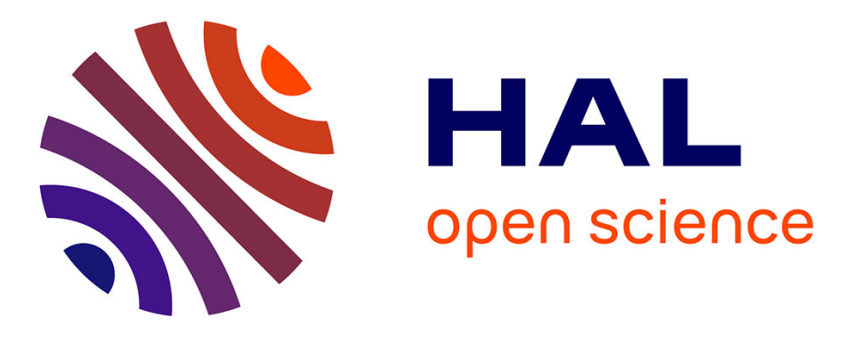

\title{
All-telluride channel waveguides for mid-infrared applications
}

C. Vigreux, M. Barillot, E. Barthelemy, Lionel Bastard, Jean-Emmanuel

Broquin, V. Kirschner, Sandie Ménard, G. Parent, C. Poinsot, A. Pradel, et al.

\section{- To cite this version:}

C. Vigreux, M. Barillot, E. Barthelemy, Lionel Bastard, Jean-Emmanuel Broquin, et al.. All-telluride channel waveguides for mid-infrared applications. Advances in Optical Materials, 2011, Istanbul, Turkey. 10.1364/AIOM.2011.AIFB7 . hal-01966804

\section{HAL Id: hal-01966804 https://hal.univ-grenoble-alpes.fr/hal-01966804}

Submitted on 16 Jan 2019

HAL is a multi-disciplinary open access archive for the deposit and dissemination of scientific research documents, whether they are published or not. The documents may come from teaching and research institutions in France or abroad, or from public or private research centers.
L'archive ouverte pluridisciplinaire HAL, est destinée au dépôt et à la diffusion de documents scientifiques de niveau recherche, publiés ou non, émanant des établissements d'enseignement et de recherche français ou étrangers, des laboratoires publics ou privés. 


\title{
All-telluride channel waveguides for mid-infrared applications
}

\author{
C. Vigreux ${ }^{1 *}$, M. Barillot ${ }^{2}$, E. Barthelemy ${ }^{1}$, L. Bastard ${ }^{3}$, J.-E. Broquin ${ }^{3}$, V. Kirschner ${ }^{4}$,

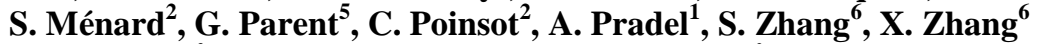 \\ ${ }^{1}$ Université de Montpellier-ICGM, France. ${ }^{2}$ Thales Alenia Space, Cannes-La-Bocca, France. ${ }^{3}$ IMEP-LAHC, Grenoble, France. ${ }^{4}$ European Space \\ Agency, Noordwijk, The Netherlands. ${ }^{5}$ Université de Nancy-Lorraine-LEMTA, France ${ }^{6}$ Université de Rennes-LVC, France. \\ *Corresponding author e-mail address: cvigreux@lpmc.univ-montp2.fr
}

\begin{abstract}
In the framework of the "Integrated Optics" project, single-mode RIB waveguides for both $[6-11 \mu \mathrm{m}]$ and $[10-20 \mu \mathrm{m}]$ spectral bands were developed in order to manufacture modal filters for spatial interferometry. In this paper, the different steps of the fabrication of such components are described and the first results in term of light guiding and modal filtering are presented.

OCIS codes: (130.3130) Integrated optics materials; (130.3060) Infrared; (160.2750) Glass and other amorphous materials
\end{abstract}

The search for Earth-like exoplanets showing biological activity is a very challenging quest. Nulling interferometry from space, in the mid-infrared, seems to be a promising technique for a direct observation of these extra-solar planets. It is studied by ESA and NASA in the framework of the Darwin and TPF-I missions, respectively. Although the studies began about 10 years ago, nulling interferometry remains a technological challenge at different stages. One of the challenges is the development of a modal filter that allows the filtering of the wavefronts to such quality that the central star flux can be rejected with an efficiency of about $10^{-5}$. The modal filter may be based on either single-mode integrated optics or fiber optics. In this paper, we are addressing the integrated optics solution.

In the framework of the Integrated Optics project, we worked on the fabrication of light-guiding structures for both $[6-11 \mu \mathrm{m}]$ and $[10-20 \mu \mathrm{m}]$ spectral bands. $\mathrm{Te}_{82} \mathrm{Ge}_{18}$ thick films of controlled thickness and refractive index were deposited by thermal co-evaporation on $\mathrm{Te}_{75} \mathrm{Ge}_{15} \mathrm{Ga}_{10}$ bulk glass substrates. Their geometry was then modified by reactive ion etching using a gas mixture of $59.5 \% \mathrm{CHF}_{3} / 10.5 \% \mathrm{O}_{2} / 30 \%$ Ar. After polishing of the input/output facets of the manufactured RIB waveguides (Figure 1), light guiding was confirmed at $\lambda=10.6 \mu \mathrm{m}$ (Figure 2). To end, the first experimental assessments of the modal filtering capability of these components were performed using a nulling interferometer operating at $\lambda=10.6 \mu \mathrm{m}$. We demonstrated light rejection efficiency of $6.10^{-5}$ using a preliminary non-optimized component. This result is very encouraging since it is in line with ESA's requirements and provides a confirmation of the potential of integrated optics for nulling interferometry.



Fig. 1. RIB waveguides: a) for the [6-11 $\mu \mathrm{m}]$ spectral band; b) for the [10-20 $\mu \mathrm{m}]$ spectral band. In both cases, the film composition is $\mathrm{Te}_{82} \mathrm{Ge}_{18}$, in order to achieve a $\Delta \mathrm{n}=\mathrm{n}_{\text {layer }}-\mathrm{n}_{\text {substrate }}=4.10^{-2}$, approximately.


Fig. 2. Evidence of the guiding properties: a) in the case of a RIB waveguide for the [6-11 $\mu \mathrm{m}]$ spectral band. Observation of a luminous spot when light $(\lambda=10.6 \mu \mathrm{m})$ is centered into the RIB structure. A $1.7 \%$ transmission was obtained, to be compared with a prediction of max. $4.5 \%$. b) Case of a RIB structure for the [10-20 $\mu \mathrm{m}]$ spectral band, observed in the 1.5-5.5 $\mu \mathrm{m}$ band using a cooled InSb infrared camera. Illuminating light is coming from a pinhole lighted by a globar infrared source. 